medRxiv preprint doi: https://doi.org/10.1101/2022.02.16.22270687; this version posted March 2, 2022. The copyright holder for this preprint (which was not certified by peer review) is the author/funder, who has granted medRxiv a license to display the preprint in perpetuity.

It is made available under a CC-BY-NC 4.0 International license .

\title{
How hostile is prolonged brain death for donor organs in transplantation? A time course analysis using clinical samples
}

KD Bera ${ }^{1,3}$, J Tabak ${ }^{2}$, RJ Ploeg ${ }^{1,3}$

1- Oxford Transplant Centre, Nuffield Department of Surgical Sciences, Oxford, UK

2- Institute of Biological and Clinical Science, University of Exeter Medical School, Exeter UK

3- Oxford University NHS Foundation Trust, Oxford, UK

\begin{abstract}
Organ donation after brain death (DBD) is an important source of transplanted organs, as chronic undersupply means many patients die whilst awaiting transplant. Improving organ quality and graft survival is key to reducing waiting lists: the interval between brain death (BD) confirmation and organ procurement offers an opportunity to reduce injury or encourage repair, yet data are lacking. Here, we developed a novel method of studying time-course changes in serum proteins in a DBD cohort from a UK biobank. Individual donor trajectories were combined into a mathematical model to allow us to determine changes in pro-inflammatory (TNF-alpha, IL-6, Complement) mediators and markers of central nervous injury (NSE, GFAP) after BD. Surprisingly, we found no evidence of a rise of TNF-alpha, NSE, IL-6 or C5a with prolonged BD, questioning the consensus view of progressively proinflammatory environment, and identified complement as a potential target for therapeutic intervention to improve organ quality.
\end{abstract}


medRxiv preprint doi: https://doi.org/10.1101/2022.02.16.22270687; this version posted March 2, 2022. The copyright holder for this preprint (which was not certified by peer review) is the author/funder, who has granted medRxiv a license to display the preprint in perpetuity. It is made available under a CC-BY-NC 4.0 International license .

Organ transplantation is a lifesaving and cost-effective treatment for patients with end-stage organ failure; however, donor organ shortages mean many patients still die whilst awaiting their transplant. In addition, many procured older and higher risk donor organs are considered untransplantable and declined by transplant centres not being utilised. To address this, it is imperative that we improve organ quality as well as maintain a good long-term transplant survival. Donation after brain death (DBD) is the most common source of deceased donor organs worldwide and, whilst a more controlled environment than procuring organs after circulatory death (DCD) who will have suffered from a respiratory and cardiac arrest, studies show comparable long term outcomes ${ }^{1,2}$. Historically, the events surrounding brain death have been described as 'hostile' including a catecholamine storm with significant haemodynamic, metabolic and hormonal changes as well as a progressive release of pro-inflammatory mediators (e.g Tumour necrosis Factor (TNF) -alpha and Interleukin (IL)-6) and activation of the complement cascade. Chemokine exposure contributes to the long-term trajectory of an organ, leading to fibrosis, impacting on long-term function and ultimately reducing graft survival $\left.\right|^{3-5}$.

To minimise the duration of grafts-to-be in this hostile environment, rapid procurement of organs was adopted. Retrospective analyses, however, demonstrate that longer duration of organ donor management in critical care actually may be beneficial for some of the transplanted organs, reducing rate of delayed graft function (DGF) for renal allografts from younger donors and without negative impact on transplanted liver or pancreas ${ }^{6,7}$. The period of brain dead organ donor management in critical care also offers a therapeutic window of intervention, yet our understanding of inflammatory processes during this period remains limited. Management of the brain dead donor has evolved and improved over decades: for example, in the UK a 'donor care bundle' used by intensivists provides guidance and donors universally receive corticosteroids ${ }^{8}$, yet detailed knowledge of how this impacts the pro- and anti-inflammatory balance is currently lacking. Animal models of brain death have been limited to a short time frame $(4-6 \text { hours })^{9-12}$. Prior studies of inflammatory serum changes in DBD organ donors measured only a limited number of time points and/or study donors with heterogenous pathologies that result in brain death ${ }^{13-18}$. We face a scenario, where understanding details of the time course surrounding brain death is key to developing strategies to reduce organ injury or promote repair, but detailed translation from preclinical studies is lacking and availability of clinical samples is limited.

Is there an approach that allows to determine (or infer) the time course of serum changes during organ donor management? We hypothesised that the selection of a donor cohort with a common 
medRxiv preprint doi: https://doi.org/10.1101/2022.02.16.22270687; this version posted March 2, 2022. The copyright holder for this preprint (which was not certified by peer review) is the author/funder, who has granted medRxiv a license to display the preprint in perpetuity.

It is made available under a CC-BY-NC 4.0 International license .

underlying pathology would enable the study the temporal changes of biomarkers of brain injury (NSE, GFAP - to reflect neuronal and glial injury, respectively) and pro-inflammatory mediators (TNFa, IL-6 and complement) in donors managed in critical care, from confirmation of brain death through to organ procurement.

The Quality in Organ Donation (QUOD) biobank contains samples from over $85 \%$ of all deceased organ donors in the UK, alongside detailed clinical donor and recipient information ${ }^{19}$. Samples, including serum and urine, are collected at clinically pre-defined time points: admission (DB1), confirmation of brain death (DB2), end of donor management (DB3), and immediately prior to removal of the donor organs (DB4). As most DBD organ donors in the UK have suffered a nonsurvivable intracranial haemorrhage (ICH), the selection of donors was limited to this pathology. Our selection criteria further identified donors with varying duration of brain death (as defined by period from confirmation of brain death to end of organ donor management but before organ procurement) to produce a cohort that included durations of brain death ranging from 10 to 30 hours. At the point of study design, we selected 268 DBD donors from the QUOD biobank with a complete set of three serum samples (DB1-3); of those, 51 donors had ICH as the documented cause of brain death, and 45/51 donors (88.23\%) had a documented brain death duration between 10 and 30 hours (mean $19.3+/-7$ hours). We excluded donors whose history included other sources of inflammation.

The cohort was further stratified into 5-hour windows of brain death duration (see Methods) with five donors per group; within each group, donors were selected to be matched for factors such as body mass index, sex, and age. This resulted in 27 selected donors. Two additional groups of donors with 'extremes' of duration of brain death were included: 'short BD' $(<10$ hours) with 2 donors and 'long BD' (>30 hours) with 5 donors. Characteristics of included donors are displayed in Table 1. A one-way ANOVA was used to evaluate the balance between the groups regarding the specified continuous parameters and confirm matched creation of study cohort. When the two extremes of BD groups are included, donor age was statistically different between all groups, with notable anticorrelation between donor age and brain death duration $\left(p=0.0017, R^{2}=0.33\right)$. This likely reflects underlying decision making: e.g., for younger donors a prolonged duration of BD might be deemed acceptable, whilst organs from older donors might be accepted when cold ischaemia time and transport duration can be minimised. 
medRxiv preprint doi: https://doi.org/10.1101/2022.02.16.22270687; this version posted March 2, 2022. The copyright holder for this preprint (which was not certified by peer review) is the author/funder, who has granted medRxiv a license to display the preprint in perpetuity.

It is made available under a CC-BY-NC 4.0 International license .

Figure 1A presents serum levels of IL-6, TNF-a, C5a, NSE and GFAP at time points of admission (sample DB1), after confirmation of brain death (sample DB2), and at the end of organ donor management (sample DB3). As each sample was taken at a clinically defined time point, comparison was only possible by setting the sample taken after confirmation of brain death as $t=0$, thus dividing the timeline into period of $\mathrm{ICH}$ management $(t<0)$ and period of organ donor management $(t>0$; once brain death is confirmed with the second brain stem test). A direct comparison to prior studies of biomarkers of brain injury and pro-inflammatory mediators is not straightforward due to heterogeneity of underlying pathologies (traumatic brain injury, ischaemic or haemorrhagic stroke, brain injury following cardiac arrest) as well as selection of different time points in a dynamic and evolving situation across studies (see Supplementary Table ${ }^{20-28}$ ).

Despite the described selection of donors with similar backgrounds and identical pathologies reducing heterogeneity and to create a representative study cohort, rules were prospectively agreed to identify and exclude outliers before creation of a time course analysis (see Methods). This resulted in the exclusion of three donors with outlying results for at least 4 of the 5 studied biomarkers. Two of the excluded donors were in the "long BD" (additional) group. Individual donor trajectories for the remaining 24 donors broken down by IL-6, TNF-a, C5a, NSE and GFAP are shown in Figure 1B.

Each donor has a unique duration of brain death before organ procurement, but combining the information from all 24 donor samples into a 'moving median' allowed us to ascertain an underlying time course. Figure $1 \mathrm{C}$ demonstrates the moving median with a window size of 20 hours for each of the serum markers from 20 hours prior to $t=0$ to 40 hours after confirmation of brain death. The moving median delineates a time course for each measured serum marker over time. The proinflammatory cytokines IL-6 and TNF-a do not follow a time course that would indicate a progressively hostile environment; TNF-a levels in serum decline from admission to end of donor management and IL-6 demonstrates a broad peak around confirmation of brain death, with subsequently decline. NSE (released from damaged neurons) and the complement cascade component $\mathrm{C} 5 \mathrm{a}$ both remain elevated from patient admission through confirmation of brain death to end of donor management. GFAP, indicating glial cell breakdown, demonstrates a step-like time course reaching plateau over the donor management period. Donor brain death is believed to occur as a result of irreversible damage to the brain stem secondary to oedema and ultimately brain stem herniation ${ }^{29}$; Our findings suggest that whilst neuronal damage leads to a steady level of released 
medRxiv preprint doi: https://doi.org/10.1101/2022.02.16.22270687; this version posted March 2, 2022. The copyright holder for this preprint (which was not certified by peer review) is the author/funder, who has granted medRxiv a license to display the preprint in perpetuity. It is made available under a CC-BY-NC 4.0 International license .

NSE from admission onwards, there is a distinct change in glial breakdown products detected in the serum around the time of confirmation of brain death reflective of large volume glial injury.

Organs from brain dead donors underperform in the long term and only function at a level comparable to organs obtained from donors after circulatory death ${ }^{1}$; DCD kidneys, for example, experience a higher rate of delayed graft function (DGF), however - if DGF remains brief - this does not translate into worse long-term recipient or graft survival ${ }^{30}$. Following confirmation of brain death whilst patients remain in critical care units, there is a logistical lag until organ procurement, we are therefore offered a window of opportunity to optimise donors further and improve organ function or reduce damage. In 2017/18 in the UK, there were on average 21 hours 48 minutes between the discussion with the donor's family and start of the procurement ${ }^{31}$. In the USA, longer donor management times are reported, which is likely a reflection of different geographical and logistical solutions to the procurement and transportation of donor organs ${ }^{32}$. Our study offers a first characterisation of the serum changes during the duration of donor management in UK critical care units, reporting alterations in key pro-inflammatory mediators as well as markers of central nervous system injury that are not usually present in human serum or plasma in the absence of injury ${ }^{33}$.

Our work has several strengths such as the use of high-quality clinical samples from a UK biobank with a high consent rate ( $>85 \%$ of all DBD donors), thus a very good representation of the overall organ donor population. Careful matching of donors, and exclusion of those where other factors could affect inflammatory markers (such as due to trauma, anoxia or infection), allowed us to infer the time-course in the 'most typical DBD donor': an isolated intracranial haemorrhage as cause for brain death. The samples that form QUOD biobank are collected based on clinical events, such as confirmation of brain death after brain stem testing, rather than set time points; this is of benefit in a situation where we do not understand the underlying time course.

Our study has limitations. Firstly, the final study cohort that allowed for matched characteristics was small (24 donors). This was due to the limiting factor of availability of the admission (DB1) sample only present in around $10 \%$ of all QUOD DBD samples. Our experimental design excluded patients where pathology preceding brain death would have been likely to produce systemic or neuroinflammation (e.g. traumatic brain injury) or are likely to differ in pathology (e.g. hypoxia), as these would confounded our results. It is possible that brain-death related changes in the markers studied could follow different trajectories in these cases. Finally, it should be noted that our goal was to understand changes representing serum levels of pro-inflammatory markers present in the donor and thus impacting the transplants-to-be, rather than detailed kinetic analysis including 
medRxiv preprint doi: https://doi.org/10.1101/2022.02.16.22270687; this version posted March 2, 2022. The copyright holder for this preprint (which was not certified by peer review) is the author/funder, who has granted medRxiv a license to display the preprint in perpetuity. It is made available under a CC-BY-NC 4.0 International license .

release or breakdown of molecules. Our approach may have broader application: it allows one to study serum changes surrounding key events using human samples and will be translatable to other clinical settings where repeat sampling is difficult, not possible or unethical.

This is the first time-course analysis of TNF-alpha, IL-6 and C5a in human DBD donors surrounding the donor care up to organ procurement. Serum changes of NSE and GFAP provide insights into the intracranial pathology with increasing release of proteins indicating progressive glial damage around confirmation of brain death.

Ultimately, however, the next questions will have to build on this to determine how we can use our findings to improve organ quality and post-transplant outcomes. Legally and ethically, treatments to the donor to improve transplantation outcomes can only be administered after brain death is confirmed, and thus understanding which pathways are amenable to intervention during this time frame is paramount. Targeting pathways or molecules that are already low or declining due to the care provided in critical care would be futile and not translate into meaningful results. Our work suggests that IL- 6 or complement should be considered as feasible targets for intervention during donor management. Histological studies of donated DBD kidneys report expression of protective, anti-inflammatory heat shock proteins (Hsp70, HO-1) alongside known pro-inflammatory mediators - with anti-inflammatory upregulation translating into protecting or restoring renal function ${ }^{34}$. Could earlier targeting of suitable pro-inflammatory mediators be sufficient to tilt the balance towards an anti-inflammatory environment, or can anti-inflammatory mediators be selectively induced? This strategy may lead to reduction or elimination of long-term fibrotic changes known to be linked to e.g. macrophage polarisation and complement mediated renal inflammation. ${ }^{5,18}$

Importantly, our study did not provide evidence that supports the previously upheld cytokine storm theory that underpins the perceived need to procure organs as quickly as possible. A recent UNOS study of cardiac transplantation showed that longer ( $>42$ hours) brain death times did not result in worse outcomes ${ }^{35}$. A study from Israel found no correlation between duration of brain death and adverse outcomes in cardiac transplantation, although short duration of brain death was defined as shorter than 97 hours $^{36}$. Our results have possible implications for further work to identify optimal procurement time points

Finally, we believe our work translates more widely by proposing a novel approach how human samples collected e.g. as part of a biobank can be used to study time courses directly in humans and guide identification of treatment targets and timings. Development of new therapies typically relies upon pre-clinical animal models. However, in cases where the underlying biology is poorly 
medRxiv preprint doi: https://doi.org/10.1101/2022.02.16.22270687; this version posted March 2, 2022. The copyright holder for this preprint (which was not certified by peer review) is the author/funder, who has granted medRxiv a license to display the preprint in perpetuity. It is made available under a CC-BY-NC 4.0 International license.

understood, an alternative approach is required. By creating a 'meta-cohort' from post hoc data, our modelling approach allowed us to use limited clinical samples to study the time-course of various biomarkers leading up to organ donation. 
medRxiv preprint doi: https://doi.org/10.1101/2022.02.16.22270687; this version posted March 2, 2022. The copyright holder for this preprint (which was not certified by peer review) is the author/funder, who has granted medRxiv a license to display the preprint in perpetuity.

It is made available under a CC-BY-NC 4.0 International license .

\section{References}

1. Gagandeep, S. et al. Expanding the donor kidney pool: utility of renal allografts procured in a setting of uncontrolled cardiac death. Am J Transplant 6, 1682-1688 (2006).

2. Müller, A. K. et al. Long-term outcomes of transplant kidneys donated after circulatory death. Nephrol Dial Transplant gfab358 (2021) doi:10.1093/ndt/gfab358.

3. Torres, I. B., Moreso, F., Sarró, E., Meseguer, A. \& Serón, D. The Interplay between Inflammation and Fibrosis in Kidney Transplantation. Biomed Res Int 2014, 750602 (2014).

4. Miller, C. L. \& Madsen, J. C. IL-6 Directed Therapy in Transplantation. Curr Transplant Rep 1-14 (2021) doi:10.1007/s40472-021-00331-4.

5. Ordikhani, F., Pothula, V., Sanchez-Tarjuelo, R., Jordan, S. \& Ochando, J. Macrophages in Organ Transplantation. Frontiers in Immunology 11, (2020).

6. Boffa, C. et al. The Impact of Duration of Brain Death on Outcomes in Abdominal Organ Transplantation: Rush and Retrieve or Relax and Repair 2017? A Retrospective UK Transplant Registry Analysis. Transplantation 101, S1 (2017).

7. Nijboer, W. N., Moers, C., Leuvenink, H. G. D. \& Ploeg, R. J. How important is the duration of the brain death period for the outcome in kidney transplantation? Transplant International 24, 1420 (2011).

8. NHS Blood and Transplant. Donation after Brainstem Death (DBD) Donor Optimisation Extended Care Bundle. http://odt.nhs.uk/pdf/dbd_care_bundle.pdf.

9. Koudstaal, L. G. et al. Brain death induces inflammation in the donor intestine. Transplantation 86, $148-154$ (2008).

10. Kolkert, J. L. P. et al. The gradual onset brain death model: a relevant model to study organ donation and its consequences on the outcome after transplantation. Lab Anim 41, 363-371 (2007).

11. Saito, Y. et al. The Influence of Brain Death on Tissue Factor Expression in the Pancreatic Tissues and Isolated Islets in Rats. Transplantation Proceedings 41, 307-310 (2009). 
medRxiv preprint doi: https://doi.org/10.1101/2022.02.16.22270687; this version posted March 2, 2022. The copyright holder for this preprint (which was not certified by peer review) is the author/funder, who has granted medRxiv a license to display the preprint in perpetuity.

It is made available under a CC-BY-NC 4.0 International license .

12. Contreras, J. L. et al. Brain death significantly reduces isolated pancreatic islet yields and functionality in vitro and in vivo after transplantation in rats. Diabetes 52, 2935-2942 (2003).

13. Lopau, K., Mark, J., Schramm, L., Heidbreder, E. \& Wanner, C. Hormonal changes in brain death and immune activation in the donor. Transpl Int 13 Suppl 1, S282-285 (2000).

14. Amado, J. A. et al. Blood levels of cytokines in brain-dead patients: relationship with circulating hormones and acute-phase reactants. Metabolism 44, 812-816 (1995).

15. Stangl, M. et al. Influence of brain death on cytokine release in organ donors and renal transplants. Transplant Proc 33, 1284-1285 (2001).

16. Schwarz, P. et al. Brain Death-Induced Inflammatory Activity is Similar to Sepsis-Induced Cytokine Release. Cell Transplant 27, 1417-1424 (2018).

17. Murugan, R. et al. Increased plasma interleukin- 6 in donors is associated with lower recipient hospital-free survival after cadaveric organ transplantation. Crit Care Med 36, 1810-1816 (2008).

18. Werkhoven, M. B. van et al. Complement Mediated Renal Inflammation Induced by Donor Brain Death: Role of Renal C5a-C5aR Interaction. American Journal of Transplantation 13, 875-882 (2013).

19. QUOD. Quality in Organ Donation website. QUOD https://quod.org.uk/for-researchers/.

20. Vos, P. E. et al. Glial and neuronal proteins in serum predict outcome after severe traumatic brain injury. Neurology 62, 1303-1310 (2004).

21. Lei, J. et al. Glial fibrillary acidic protein as a biomarker in severe traumatic brain injury patients: a prospective cohort study. Crit Care 19, 362 (2015).

22. El-Maraghi, S., Yehia, H., Hossam, H., Yehia, A. \& Mowafy, H. The prognostic value of neuron specific enolase in head injury. The Egyptian Journal of Critical Care Medicine 1, 25-32 (2013).

23. Antunes, A. A. et al. Interleukin-6 Plasmatic Levels in Patients with Head Trauma and Intracerebral Hemorrhage. Asian J Neurosurg 5, 68-77 (2010). 
medRxiv preprint doi: https://doi.org/10.1101/2022.02.16.22270687; this version posted March 2, 2022. The copyright holder for this preprint (which was not certified by peer review) is the author/funder, who has granted medRxiv a license to display the preprint in perpetuity.

It is made available under a CC-BY-NC 4.0 International license .

24. Hergenroeder, G. W. et al. Serum IL-6: a candidate biomarker for intracranial pressure elevation following isolated traumatic brain injury. J Neuroinflammation 7, 19 (2010).

25. Moseby-Knappe, M. et al. Serum markers of brain injury can predict good neurological outcome after out-of-hospital cardiac arrest. Intensive Care Med (2021) doi:10.1007/s00134-021-06481-

4.

26. Mocco, J. et al. Alterations in plasma complement levels after human ischemic stroke.

Neurosurgery 59, 28-33; discussion 28-33 (2006).

27. Mack, W. J. et al. Early plasma complement C3a levels correlate with functional outcome after aneurysmal subarachnoid hemorrhage. Neurosurgery 61, 255-260; discussion 260-261 (2007).

28. Stein, D. M. et al. Relationship of Serum and Cerebrospinal Fluid Biomarkers With Intracranial Hypertension and Cerebral Hypoperfusion After Severe Traumatic Brain Injury. Journal of Trauma and Acute Care Surgery 70, 1096-1103 (2011).

29. Ujihira, N., Hashizume, Y. \& Takahashi, A. A clinico-neuropathological study on brain death. Nagoya J Med Sci 56, 89-99 (1993).

30. Phillips, B. L. et al. Effect of delayed graft function on longer-term outcomes after kidney transplantation from donation after circulatory death donors in the United Kingdom: A national cohort study. American Journal of Transplantation 21, 3346-3355 (2021).

31. Curtis, R., Johnson, R., Gardiner, D., Mumford, L. \& McGowan, O. The length of the deceased organ donation and transplantation process. (2019).

32. Jawitz, O. K. et al. Time from Lung Transplant Donor Brain Death to Cross Clamp: An Analysis of the UNOS Registry. The Journal of Heart and Lung Transplantation 38, S190 (2019).

33. Huebschmann, N. A. et al. Comparing Glial Fibrillary Acidic Protein (GFAP) in Serum and Plasma Following Mild Traumatic Brain Injury in Older Adults. Frontiers in Neurology 11, 1054 (2020).

34. Nijboer, W. N. et al. Effects of brain death on stress and inflammatory response in the human donor kidney. Transplantation Proceedings 37, 367-369 (2005). 
medRxiv preprint doi: https://doi.org/10.1101/2022.02.16.22270687; this version posted March 2, 2022. The copyright holder for this preprint (which was not certified by peer review) is the author/funder, who has granted medRxiv a license to display the preprint in perpetuity.

It is made available under a CC-BY-NC 4.0 International license.

35. Jawitz, O. K. et al. Influence of donor brain death duration on outcomes following heart transplantation: A United Network for Organ Sharing Registry analysis. The Journal of Thoracic and Cardiovascular Surgery 159, 1345-1353.e2 (2020).

36. Kogan, A. et al. Does duration of donor brain injury impact heart transplantation outcomes? Clinical Transplantation 33, e13660 (2019). 
medRxiv preprint doi: https://doi.org/10.1101/2022.02.16.22270687; this version posted March 2, 2022. The copyright holder for this preprint (which was not certified by peer review) is the author/funder, who has granted medRxiv a license to display the preprint in perpetuity.

It is made available under a CC-BY-NC 4.0 International license .

\section{Methods}

\section{Donor cohort and serum sample selection process}

Serum samples from the UK QUOD biobank were selected to study the brain death period between 10 and 30 hours (from confirmation of brain death by completed second brain stem test to organ procurement). Inclusion criteria used were: presence of valid consent; availability of three serum samples (before brain death; after confirmation of brain death, at end of donor management period); intracranial haemorrhage as cause leading to brain death, as well as the documented duration of brain death. The following exclusion criteria were used: incomplete set of serum samples; other causes of brain death (such as but not limited to hypoxic brain injury, trauma, ischaemia, infection); documented systemic source of elevated inflammatory markers (trauma, documented infection such as e.g. pneumonia or urinary infection). To allow selection of donors who were similar in characteristics other than the duration of brain death, the 20-hour period was broken down into four 5-hour blocks (10-15 hours, 15-20 hours, 20-25 hours, 25-30 hours of brain death) and for each block, donors were selected to be balanced for age, gender, body mass index, co-morbidities (especially hypertension and diabetes), duration of cold ischemia time and renal function after transplantation. The inclusion of the latter two allowed to ensure that the selection of donors was not biased to those with particularly good or bad post-transplant outcomes. In addition, donors who fulfilled all inclusion criteria but had documented 'extremes' of brain death $(<10 \mathrm{~h}$ or $>30 \mathrm{~h}$ ) were also included to allow study of time course either side of the core time frame. All included donors had a complete set of serum samples, however for six donors the exact time point of the first sample collection at time of admission was not documented, the time and date of admission recorded by NHSBT was used instead. The donors with one missing time point were evenly distributed between the brain death groups. The QUOD programme research approval as a Research Tissue Bank (REC ref 13/NW/0017, from North West - Greater Manchester Central Research Ethics Committee,) covers the provision of data and research samples for research into improving the quality of organ quality for transplantation. The approval applies to all research projects conducted in the UK using tissue or data supplied by the tissue bank. The favourable REC decision confirmed that further project-based ethical approval applications (by individual researchers) are not deemed necessary.

\section{Enzyme linked immune absorption assay (ELISA)}

All received samples were stored at $-80 \mathrm{C}$ before use. DuoSet ${ }^{\oplus}$ ELISA Kits (R\&D Systems) for human Interleukin-6, Tumour Necrosis Factor-alpha, Complement 5a, Neuron Specific Enolase and Glial 
medRxiv preprint doi: https://doi.org/10.1101/2022.02.16.22270687; this version posted March 2, 2022. The copyright holder for this preprint (which was not certified by peer review) is the author/funder, who has granted medRxiv a license to display the preprint in perpetuity.

It is made available under a CC-BY-NC 4.0 International license .

Fibrillary Acid Protein were used according to the manufacturer's instructions. Each sample was measured in duplicates using a Bio-Rad iMark $^{\mathrm{TM}}$ Microplate Reader. MatLab and GraphPad Prism9 were used for data analysis. In brief, the average value from the duplicate measurements (followed by transformation using $\ln (\mathrm{Y}+1))$ was used for the time course plots (Fig 1).

Moving median analysis Before combined analysis of donor serum levels, the ROUT method was used to identify outliers. Donors which were identified as having outlier results for at least four of the five measured serum molecules $(Q=0.1 \%)$ were excluded before a moving median was calculated. This analysis removed three donors - one from the 25-30h brain death duration group and two from the $>30 \mathrm{~h}$ brain death group (one of which was a donor with missing admission time point). Subsequently, data for all remaining donors was combined using moving median plots for each serum level of the molecules. In detail, the time of brain death confirmation was defined as $t=$ 0 for each donor. We constructed a moving median for the 20-hour period before confirmation of brain death, and the 40-hour period following brain death. For the 20 -hour period before confirmation of brain death, we replaced each level by the median of all levels within a 20 hour window centered on that point and sampled before $t=0$. Similarly, for the 40 -hour period of time after confirmation brain death, we used a 20-hour moving window using only levels sampled after $\mathrm{t}$ $=0$. Using a shorter window moving median would have made the implicit assumption that all points belonged to the same time series, whilst cytokine levels may not follow equivalent time courses in each donor. For $\mathrm{t}=0$ the median of all samples at this time point was used.

\section{Acknowledgments}

The authors would like to thank Dr Sergei Maslau for his help with the initial selection of the study cohort and Dr Michael Craig for his thoughts and comments on earlier versions of the manuscript. 
medRxiv preprint doi: https://doi.org/10.1101/2022.02.16.22270687; this version posted March 2, 2022. The copyright holder for this preprint (which was not certified by peer review) is the author/funder, who has granted medRxiv a license to display the preprint in perpetuity.

It is made available under a CC-BY-NC 4.0 International license.

We would like to thank all organ donors and their families - none of this work would be possible without them. This study was made possible by obtaining samples and data from the UK QUOD Biobank which is a partnership programme between UK academic transplant centres and NHS Blood and Transplant.

\section{Declaration of competing interests and funding}

KDB was supported by the National Institute for Health Research (NIHR) with an NIHR Academic Clinical Fellowship. KDB received a pump priming research grant from the Oxford Transplant Foundation to support this project (R56956/AA001)

RJP is the PI for the Quality in Organ Donation (QUOD) programme

The remaining authors declare they have no competing interests. 
Table 1. Clinical characteristics of final study cohort.

\begin{tabular}{|c|c|c|c|c|c|c|c|c|c|c|}
\hline & donor & & & & & & & recipient & & \\
\hline Group & $\begin{array}{l}\text { Brain death } \\
\text { (h) }\end{array}$ & Age & $\mathrm{BMI}$ & HTN & DM & Creatinine $^{1}$ & $\begin{array}{l}\text { Cold ischemia } \\
\text { time (h) }\end{array}$ & Age & $\mathrm{BMI}$ & eGFR at 12 months \\
\hline $\begin{array}{l}1 \\
<10 h\end{array}$ & $5.9+/-4.0$ & $73+/-8.3$ & $\begin{array}{l}31.7 \\
+/- \\
0.5 \\
\end{array}$ & $\begin{array}{l}2 / 2 \\
\text { HTN }\end{array}$ & $1 / 2 \mathrm{DM}$ & $85.0+/-8.4$ & $14.1+/-0.7$ & $\begin{array}{l}67.5+/- \\
0.7\end{array}$ & $\begin{array}{l}24.1+/- \\
0.6\end{array}$ & $49.5+/-33.9$ \\
\hline $\begin{array}{l}2 \\
10-15 h\end{array}$ & $13.1+/-1.9$ & $\begin{array}{l}51.4+/- \\
11.3\end{array}$ & $\begin{array}{l}24.8 \\
+/- \\
2.7 \\
\end{array}$ & $\begin{array}{l}0 / 5 \\
\text { HTN }\end{array}$ & 0/5 DM & $62.4+/-9.8$ & $13.6+/-5.3$ & $\begin{array}{l}51.6+/- \\
16.5\end{array}$ & $\begin{array}{l}22.6+/- \\
5.3^{3}\end{array}$ & $49.2+/-8.5$ \\
\hline $\begin{array}{l}3 \\
15-20 h\end{array}$ & $17.9+/-1.4$ & $\begin{array}{l}53.6+/- \\
6.2\end{array}$ & $\begin{array}{l}31.7 \\
+/- \\
6.9 \\
\end{array}$ & $\begin{array}{l}3 / 5 \\
\text { HTN }\end{array}$ & 1/5 DM & $66.6+/-18.8$ & $13.2+/-1.2^{2}$ & $\begin{array}{l}55.0+/- \\
1.8\end{array}$ & $\begin{array}{l}25.53+/- \\
5.3^{3}\end{array}$ & $48.6+/-14.1$ \\
\hline $\begin{array}{l}4 \\
20-25 h\end{array}$ & $22.6+/-1.9$ & $\begin{array}{l}49.2+/- \\
8.1\end{array}$ & $\begin{array}{l}29.0 \\
+/- \\
5.7 \\
\end{array}$ & $\begin{array}{l}1 / 5 \\
\text { HTN }\end{array}$ & $1 / 5 \mathrm{DM}$ & $59.4+/-24.0$ & $18.3+/-6.0$ & $\begin{array}{l}47.4+/- \\
19.3\end{array}$ & $\begin{array}{l}26.4+/- \\
5.0^{2}\end{array}$ & $65.4+/-44.7$ \\
\hline $\begin{array}{l}5 \\
25-30 h\end{array}$ & $26.5+/-1.6$ & $\begin{array}{l}48.8+/- \\
10.4\end{array}$ & $\begin{array}{l}25.9 \\
+/- \\
3.4 \\
\end{array}$ & $\begin{array}{l}1 / 5 \\
\text { HTN }\end{array}$ & $1 / 5 \mathrm{DM}$ & $59.4+/-24.0$ & $14.4+/-4.0$ & $\begin{array}{l}42.2+/- \\
19.7\end{array}$ & $\begin{array}{l}27.5+/- \\
5.5\end{array}$ & $51.8+/-19.7$ \\
\hline $\begin{array}{l}6 \\
>30 h\end{array}$ & $33.0+/-3.6$ & $\begin{array}{l}36.6+/- \\
15.1\end{array}$ & $\begin{array}{l}32.7 \\
+/- \\
9.8 \\
\end{array}$ & $\begin{array}{l}1 / 4 \\
\text { HTN }^{2}\end{array}$ & $1 / 5 \mathrm{DM}$ & $83.8+/-33.0$ & $18.2+/-6.1$ & $\begin{array}{l}40 .-+/- \\
19.8^{2}\end{array}$ & $\begin{array}{l}24.8+/- \\
1.29^{2}\end{array}$ & $56.8+/-20.3$ \\
\hline $\begin{array}{l}P \\
\text { value } \\
(2-5)\end{array}$ & $<0.0001$ & 0.833 & 0.16 & & & 0.95 & 0.70 & 0.63 & 0.74 & 0.70 \\
\hline $\begin{array}{l}P \\
\text { value } \\
(1-6)\end{array}$ & $<0.0001$ & 0.015 & 0.28 & & & 0.45 & 0.42 & 0.37 & 0.72 & 0.89 \\
\hline
\end{tabular}

Overview of created study cohort created by selecting donors with intracranial haemorrhage (ICH), a documented length of brain death and full set of serum samples; donors selected to be matched to within $5 \mathrm{~h}$ groups of brain death. Extremes of post-transplantation outcome were excluded, as were donors with documented other sources of inflammatory changes such as trauma or infection. All characteristics shown in mean +/-SD. 1 at offer $2 n=1$ missing data point $3 n=2$ missing data points 4 One way ANOVA; all shown as mean +/- S.D. 


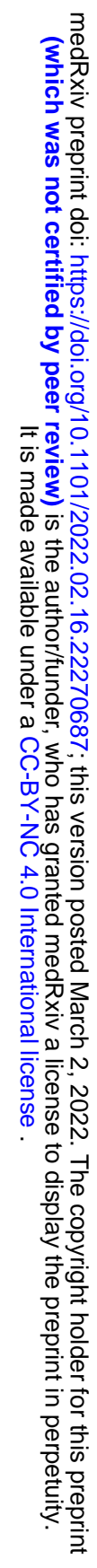


A
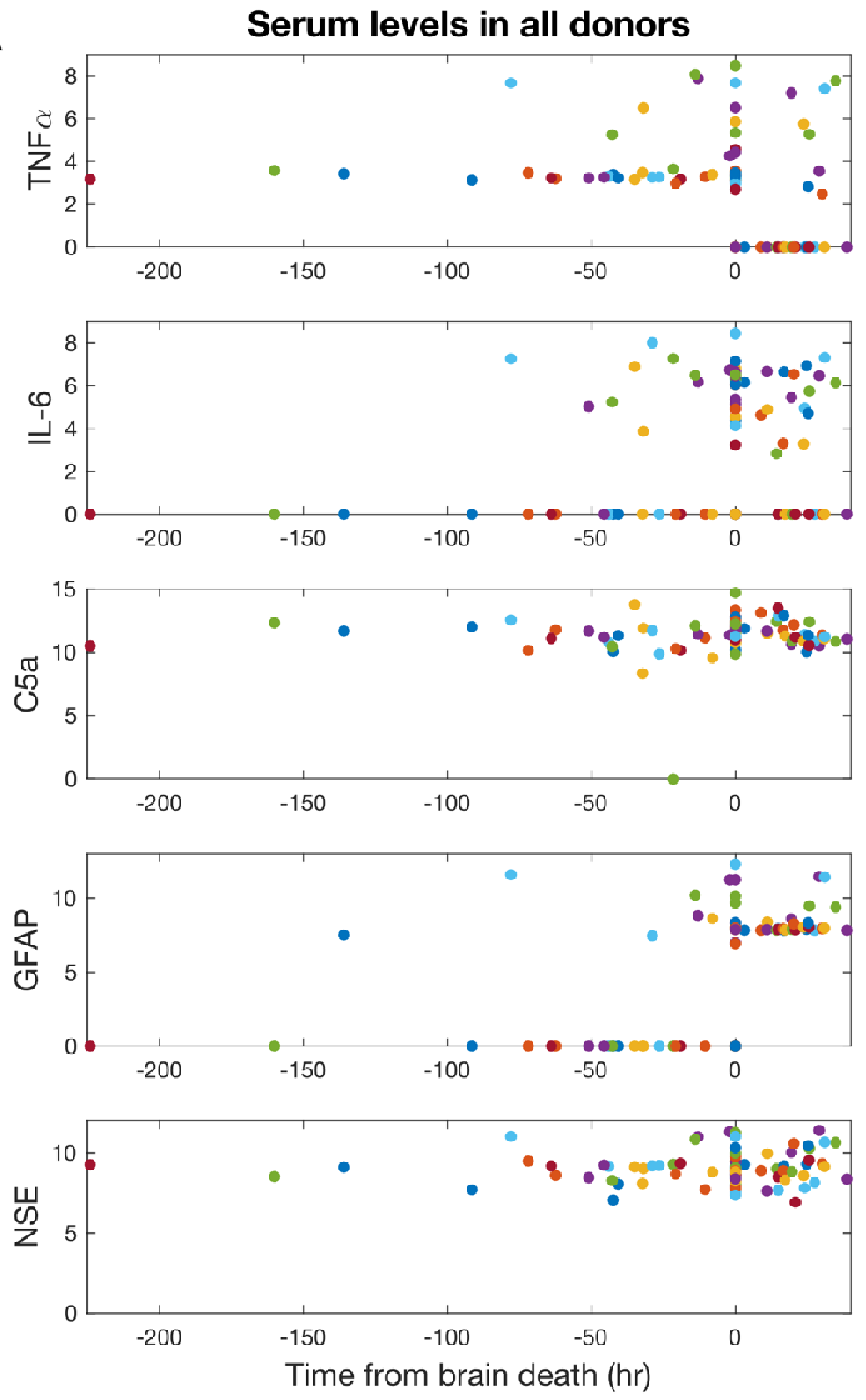

B Serum Levels in 24 Donors
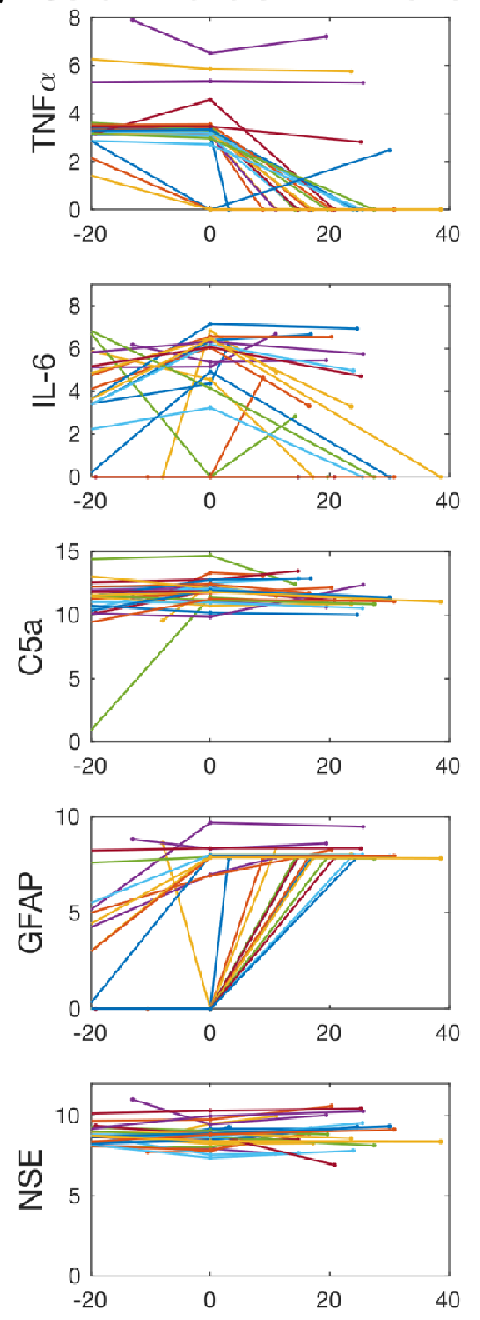

Time from brain death (hr)
C Moving median
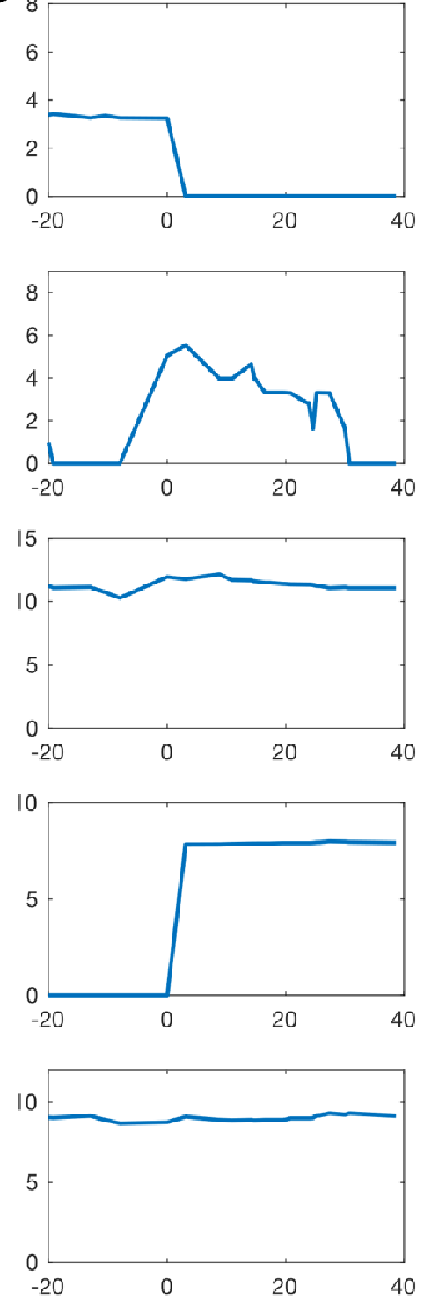

Time from brain death (hr) 
Figure 1. Serum time course analysis. Each row represents serum levels for one of the studied biomarkers: Tumour Necrosis Factor alpha (TNF?), Interleukin-6 (IL-6), Complement C5a, Glial Fibrillary Acidic Protein (GFAP) and Neuronal Specific Enolase (NSE), all levels shown in $\ln (y+1)$. For each donor, three samples based on clinically defined time points (DB1, DB2, D3) were measured, DB2 was set as $t=0$ to allow comparison. Panels A, B, C show analysis of serum levels from individual sample levels to combined time course analysis. (A) Comparison of serum levels of the whole donor cohort, each donor in different colour. (B) donor trajectories of final donor cohort (connecting lines depict individual donor trajectories). (C) calculated moving median to demonstrate time course for each biomarker (moving median window of 20 hours). 